\title{
The Effect of Nutrition Food Diversity Assistance on Weight Gain of Undernourished Toddlers at Jambi City
}

\author{
$1^{\text {st }}$ Rusmimpong \\ Nutrition Departemen \\ Politeknik Kesehatan Kemenkes Jambi \\ Jambi, Indonesia \\ rusmimpong@yahoo.com
}

\author{
$2^{\text {nd }}$ Daryono \\ Nutrition Departemen \\ Politeknik Kesehatan Kemenkes Jambi \\ Jambi, Indonesia \\ daryono@gmail.com
}

\author{
$3^{\text {rd }}$ Erna Heryani \\ Nutrition Departemen \\ Politeknik Kesehatan Kemenkes Jambi \\ Jambi, Indonesia \\ ernaheryani@gmail.com
}

Corresponding Author: rusmimpong@yahoo.com

Abstract-Nutritional problems are still at the center of attention in developing countries. By 2030 the Sustainable Development Goals (SDGs) aim to end all forms of malnutrition. Risk factors for underweight besides nutrient intake and infectious diseases, maternal factors, environmental factors and diet also have a contribution. The research is expected to contribute to the monitoring of food diversity improvement programs to accelerate the reduction in the incidence of stunting in Jambi Province. This study aims to determine the effect of food diversity assistance on weight gain of children under five. This type of research is quasi experimental. This research was conducted in the working area of Puskesmas Paal $\mathrm{V}$ and Simpang Kawat, Jambi City. The research period was from June to November 2019. The sample in the study was underweight toddlers (malnutrition and malnutrition) in the work area of Puskesmas Paal V and Simpang Kawat, Jambi City, totaling 40 people who were given PMT. The data was collected by conducting interviews and measuring the weight of the toddler. The interventions provided were in the form of health education and food diversity assistance for mothers of children under five in providing nutrition to their children. The intervention was carried out for 30 days. Data analysis used univariate and bivariate analysis. The results showed that the average food diversity score of children under five before the intervention was 4.13 and after the intervention the average food diversity score was 6.40. There is an effect of food diversity assistance on increasing the behavior of mothers in giving various foods and there is an increase in the weight of children under five who are malnourished after being given food diversity assistance with an average increase of 9.67. Recommendations for family empowerment in providing food diversity to their toddlers, it is necessary to review the calculation of the nutritional needs of children under five and the ideal body weight of toddlers for the accuracy of the amount of PMT given to toddlers based on the energy deficiency category, planning homecare based nutrition improvement activities.

Keywords: mentoring, food diversity, body weight, toddlers, malnutrition.

\section{INTRODUCTION}

One of the Sustainable Development Goals (SDGs) is to end all forms of malnutrition by 2030 (1).The main target to improving the community nutrition status in National Medium- Term Development Plan (Rencana Pembangunan Jangka Menengah Nasional / RPJMN) 2015-2019 is to prevent wasting toddler and to decrease it from $12 \%$ to $9,5 \%$. Baseline Health Research (Riset Kesehatan Dasar/Riskesdas) on 2010, 2013 and 2018 show no significant change on the prevalence of malnourished children. The prevalence of severe and moderate malnutrition in toddler in 2010 was $17,9 \%$, on 2013 become $19,6 \%$ and decreased to $17,7 \%$ on 2018 (2). Good food diversity assistance for families can influence children nutritional status. One of the government's efforts to overcome the malnutrition problem was with supplementary feeding program which is customized with the nutrition needs 
to improve the nutritional status (3) Feeding pattern in children care was affected by mother knowledge and educational background (Abuya, et al, 2012). Educational level of the parents was a strong determinant on children nutritional problem in Indonesia and Bangladesh (4).

A research by on the Influence of the use of nutrition action cards in Toddler care at the working area of Puskesmas Tahtul Yaman Jambi City showed an improvement on cadre's knowledge after training using nutriotion action cards from 5,83 to 9,25 and an escalation on children feeding behaviour by $13,1 \%$ after cadre assistance for 7 days. Nutrition action cards were given to the mother which contain notes about everyday food guidance for their toddlers (5). Mothers asked to wrote actively in the cards all the food type that given to their children within the day. The card hopefully could become tool to educate mothers on mother's behaviour to feed their children. The Nutrition cards was also expected to be a screening tool for food diversity and improvement of nutritional status in malnourished children. Although food diversity assistance has been proofed in increasing the mother's feeding behaviour, it still to be investigated how this program could impact on the toddlers' weight status, especially in undernourished children. This study aimed to identify the effect of nutritional diversity assistance on weight gain of undernourished toddlers in Jambi city.

\section{METHODS}

This was a quasi-experimental study on 40 undernourished toddlers from the Puskesmas Paal V and Puskesmas Simpang Kawat working area (20 samples from each Puskesmas). Samples were selected from the Puskesmas and Posyandu database, followed by home visit interview, fulfilling the checklist and crosschecked by measuring the toddlers weight and height. The length and the weight when their toddlers were born were asked to the mother and validated by looking at the toddler's Growth monitor cards. For the variable underweight were compared to the age using assessment indicator from 2005 WHO standard. The samples recruited in this study were all the toddlers that meet all the criteria of undernourished child. Cadre from the Puskesmas working area (Posyandu's officer) also recruited and trained to assist the mother along the research. Sample then divided into control and intervention group. For intervention will be assisted by te nutrion food diversity assistance.

The study begun by teaching the mother how to fill the nutrition active card, educate them how to choose variety of food to feed their toddlers. The first observation were done at 24 hours after the card given. The card were thoroughly checked using a checklist to determine the diversity of food given. The data was collected as the pre-test. Followed by assisting the mother to plan their children nutrition needs for the next 14 days. At the 14th day, another evaluation of the nutritional active card were done to assess the food diversity. The data then collected as the post-test.

On the first day, questions were asked to the mothers about mother's behaviour and food diversity. Mother behavior questions including the history of early initiation of breastfeeding when their child was a newborn, exclusive breastfeeding and continuing the breastfeeding until 2 years, whether they give their children complete immunization and regularly checked their children growth at Posyandu or not. Food diversity define by a mother's behaviour on feeding their toddlers at the past 24 hours (ranging from wake up till going back to sleep) and noted in the nutritional action card.

The assessment categorized well food diversity if the mother feed their toddler at the first observation and the 14th day as it should be (according to the guidelines on the nutrition action card). The mother was asked to write down the food that had been given to the toddler at the past 24 hours. The first day's data is the data before the mentoring. After that, researchers provide health education to mothers about good nutrition for toddlers as well as the diversity of food given to toddlers. The second day the enumerator (posyandu officer) visits back to the toddler's mother's house and asks what food has been given to the toddler 24 hours ago. Officers evaluate the diversity of food given to toddlers on the second day. From the evaluation results, health officials discussed with the toddler's mother about the nutrition given to her toddler. If the mother gives nutrition to her toddler is still not categorized either, then the psksesmas officer discusses back with the mother about the diet that should be given by the mother to her toddler. This activity is carried out continuously until the 14th day. Day 14 is the last day of evaluating maternal parenting patterns for 14 consecutive days. The behavior of the mother to give nutrition to her toddler on the 14th day (last) is the data used as post test data.

Bivariate analysis was used to determine the effect of nutrition food diversity assistance using dependent $t$ tests for normal distributed data or wilcoxon tests for abnormally distributed data. 


\section{RESULTS}

The distribution frequency of mothers characteristic shows in table 1, while characteristics of mothers based on maternal parenting patterns can be seen on table 2. The results showed that most $(67.5 \%)$ mothers of the respondents have high school education levels and most $(97.5 \%)$ of them were a housewife.

Table 1. Distribution of Education and occupation of Toddler's Mothers in The Work Area of Puskesmas in Jambi

\begin{tabular}{clcc}
\hline No & \multicolumn{1}{c}{ Characteristics } & $\mathrm{N}$ & $\%$ \\
\hline 1 & Education & 7 & \\
& Elementary school & 1 & 2,5 \\
& Junior High School & 27 & 67,5 \\
& High School & 5 & 12,5 \\
\hline University & 39 & 97,5 \\
\hline 2 & Mother's Occupation & 1 & 2,5 \\
\hline & Housewife & \\
& Civil Servants/Police/Army & & \\
\hline
\end{tabular}

Table 2. Distribution of Toddler Mothers Based on Parenting Patterns in The Work Area of Puskesmas at Jambi City

\begin{tabular}{clcc}
\hline No & Parenting Patterns & N & $\%$ \\
\hline 1 & Good & 28 & 70.0 \\
2 & Not Good Enough & 12 & 30.0 \\
\hline & Amount & 40 & 100 \\
\hline
\end{tabular}

Table 2 explains that as many as $70 \%$ of toddler mothers have a good parenting pattern towards their toddler. Characteristics of toddlers can be seen in table 3 .

Table 3. Average Distribution of toddlers

\begin{tabular}{lccc}
\hline \multicolumn{1}{c}{ Variable } & Mean & Median & Min-Max \\
\hline Toddler Age & 28.48 & 27.50 & $8-59$ \\
\hline Birth Weight & 2910 & 2900 & $2400-3400$ \\
\hline Children number & 2.03 & 2,00 & $1-5$ \\
\hline
\end{tabular}

Table 3. shows that the average age of toddlers studied was 28.48 months and the average weight of the toddlers when they were born was 2910 grams. Most of the toddlers in this study were child number 2 . The effect of nutrition food diversity assistance on food diversity and weight gain shows in table 4.
Table 4. The effect of nutrition food diversity assistance on food diversity and weight gain in The Working Area of Puskesmas in Jambi City

\begin{tabular}{llllll}
\hline Variable & Mean & Median & Sd & Pvalue $^{*}$ & $\mathrm{~N}$ \\
\hline Food Diversity & & & & & \\
Intervention Group & 2,75 & 3,0 & 1,33 & 0,022 & 20 \\
Control Group & 1.8 & 1.5 & 1.1 & & \\
\hline $\begin{array}{l}\text { Weight Gain of } \\
\text { Toddler }\end{array}$ & & & & & \\
$\begin{array}{l}\text { Intervention Group } \\
\text { Control Group }\end{array}$ & 0,225 & 0,200 & 0,148 & 0,031 & 20 \\
& 0,125 & 0,150 & 0,107 & &
\end{tabular}

*Wilcoxon test

Table 4 showed that there were significant difference of maternal behavior in providing diversity of food to their toddlers from day one to the $14^{\text {th }}$ day between control and intervention group. The group given assistance had a behavioral improvement of 2.75 compared to control of 1.8 . Wilcoxon test results showed $\mathrm{p}$ value of 0.022 . That means there was a significant influence of food diversity assistance on improving maternal behavior to provide diversity of food to the toddler.

\section{DISCUSSIONS}

A similar result from previous research showed that a regular nutrition education for mother in conjunction with supplementary feeding intervention can improved the mothers feeding pattern, such as meal frequency, dietary diversity and water quality (6). While the effect of food diversity assistance on the weight gain of the toddlers from day one to the $14^{\text {th }}$ day also showed a significant different between intervention and control group, as much as 0.225 average of weight gain in the group given assistance compared to the group that was not given assistance which was only 0.125 . The wilcoxon test analysis showed a $\mathrm{p}$ value of 0.031 , which means there was a significant influence of food diversity assistance on the weight gain of toddlers.

Lack of food diversity is one of the factors causing malnutrition and stunting in toddlers (7). Diversity in diet intake helps to ensure adequate essential nutrients for the body especially for toddlers in their growth age (8). Dietary diversity defined as the sum of food intake over a period of 24 hours and has been used as an easyto- measure key indicators by the World Health Organization (WHO) to asses feeding pattern of the child. Food diversity also has been used worldwide as a valid and reliable predictor of dietary quality among infants and young children (9). 


\section{CONCLUSIONS}

Nutrition food diversity assistance has significant effect on food diversity and toddlers weight gain after giving te food diversity assistance 14 days compare to control group.

\section{REFERENCES}

[1] Amoroso L. Agenda and Sustainable Development Goals: Where Are We Now? Global Opportunities to Address Malnutrition in all Its Forms, Including Hidden Hunger. In Hidden Hunger: Strategies to Improve Nutrition Quality. Karger Publ. 2018; Vol. 118:p 45-56.

[2] Kemenkes. Hasil utama RISKESDAS 2018. Online. 2018. p. http://www. depkes. go. id/resources/download/info.

[3] Khasanah, D.P; Hamam, H; and Bunga A. Waktu Pemberian Makanan Pendamping ASI (MP-ASI) Berhubungan dengan Kejadian Stunting Anak Usia 6-23 bulan di Kecamatan Sedayu. J Gizi dan Diet Indones. 2016;4 (2):105-11.

[4] Semba RD, de Pee S, Sun K, Sari M, Akhter N BM. Effect of parental formal education on risk of child stunting in Indonesia and Bangladesh: a cross-sectional study. Lancet. 2008;26 (22):322-71.

[5] Junita, J., Rusmimpong, R., \& Putra ES. Junita, J., Rusmimpong, R., \& Putra, E. S. (2020). Pendampingan Kader Menggunakan Kartu Aksi Gizi Meningkatkan Pola Asuh Ibu. Jurnal Vokasi Kesehatan, )6(1, 6-12.J Vokasi Kesehat. 2020;6 (1):6-12.

[6] Kajjura, R. B., Veldman, F. J., \& Kassier SM. Effect of nutrition education on knowledge, complementary feeding, and hygiene practices of mothers with moderate acutely malnourished children in Uganda. Food Nutr Bull. 2019;40 (2):221-230.

[7] Damanik, S. M., Wanda, D., \& Hayati H. Feeding practices for toddlers with stunting in Jakarta: A case study. 12(Suppl 1). Pediatr Rep. 2020;12:supp; 1.

[8] Ouédraogo, O., Wendinpuikondo Raketa Compaoré, E., Kou'santa Sabiba Amouzou, E., \& Hama Dicko M. Ouédraogo, O., Wendinpuikondo Raketa Compaoré, E., Kou'santa Sabiba Amouzou, E., \& Hama Dicko, M. (2019). Toddlers' Dietary Diversity and Its Determinants in Different Agricultural Periods. Int Nutr Sci. 2019;4(3):151-61.

[9] Moramarco, S., Amerio, G., Chafula Muyaba, L., Bonvecchio, D., Abramo, E., Palombi, L., \& Buonomo E. Nutritional counseling improves dietary diversity and feeding habits of Zambian malnourished children admitted in Rainbow nutritional programs. Biomed. 2017;Prev, 1. 